GRASAS Y ACEITES 72 (4)

October-December 2021, e436

ISSN-L: 0017-3495

https://doi.org/10.3989/gya.1006202

\title{
Effects of an integrated harvest system on the quality of olive fruit for small producers
}

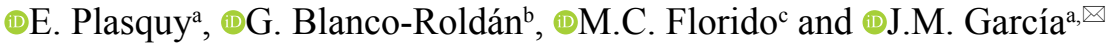 \\ anstituto de la Grasa. Departamento de Bioquímica y Biología Molecular de Productos Vegetales (CSIC). Carretera Sevilla Utrera km 1. \\ Campus de la UPO, Edificio 46, 41013, Seville, Spain. \\ bG.I. AGR 126 "Mecanización y Tecnología Rural”. E.T.S.I.A.M. Universidad de Córdoba. Campus Rabanales, Ed. Leonardo Da Vinci, \\ Ctra. Nacional IV, km. 396. 14014. Córdoba. \\ 'Departamento de Cristalografía, Mineralogía y Química Agrícola, E.T.S.I.A. Universidad de Sevilla. Carretera Sevilla Utrera km 1, \\ 41013, Seville, Spain. \\ ${ }^{\otimes}$ Corresponding author: jmgarcia@ig.csic.es
}

Submitted: 06 October 2020; Accepted: 23 November 2020; Published online: 12 January 2022

SUMMARY: Small producers confront specific challenges when they opt to produce high-quality olive fruit. Limited resources for investing in harvest machinery and manpower are the main reasons for continuing a traditional harvest method that puts the final product and its economic value at risk. This paper discusses the efficiency of an integrated harvest system as a possible solution to these specific challenges. The system is formed by a newly designed manual harvesting device and the use of a cooling room near the olive grove. Both systems were evaluated to assess their feasibility for optimum conditions before processing. The combined effect of the harvesting method and cold storage on the fruit characteristics (incidence of decay, skin color, weight loss, firmness, respiration, and ethylene production) was evaluated on three different varieties ('Arbequina', 'Picual' and 'Verdial') and four different storage times ( $0,4,8$, and 14 days). The results indicate that the proposed harvesting method in combination with an appropriate cooling system offers an affordable alternative for obtaining fruit with the best physiological characteristics.

KEYWORDS: Branch-shaker; Cold-storage; Inverted umbrella; Olea europaea; Fruit quality

RESUMEN: Efectos de un sistema integrado de recolección para pequeños productores en la calidad de la aceituna recogida. Los pequeños productores se enfrentan a retos específicos, cuando optan por producir aceitunas de alta calidad. La imposibilidad económica de invertir, tanto en maquinaria de cosecha, como en mano de obra es la razón principal que obliga a continuar una recolección tradicional que pone en riesgo el producto final y su valor económico. Este estudio analiza la eficiencia de un sistema de recolección integrado como una posible solución a estos desafíos específicos. El sistema está formado por un dispositivo de recogida manual de nuevo diseño y el uso de una cámara de frío en la finca. El efecto combinado del método de recolección presentado y el almacenamiento en frío sobre las características de la fruta (incidencia de podredumbre, color de piel, pérdida de peso, firmeza, respiración y producción de etileno) se evaluó en tres variedades diferentes ('Arbequina', 'Picual' y 'Verdial') y diferentes tiempos de almacenamiento ( $0,4,8,14$ días). Los resultados indican que la combinación de un método de recolección mecánica y un sistema de enfriamiento adecuado ofrece una alternativa económicamente asequible para obtener frutos con las mejores características fisiológicas.

PALABRAS CLAVE: Calidad del fruto; Conservación en frío; Olea europaea; Paraguas invertido; Vibrador de rama

Citation / Cómo citar este artículo: Plasquy E, Blanco-Roldán G, Florido MC, García JM. 2021. Effects of an integrated harvest system on the quality of the olive fruit for small producers. Grasas Aceites 72 (4), e436. https://doi.org/10.3989/gya.1006202

Copyright: (C2021 CSIC. This is an open-access article distributed under the terms of the Creative Commons Attribution 4.0 International (CC BY 4.0) License. 


\section{INTRODUCTION}

While it is well-know that Spain stands out as the major producer of olive oil and table olives in the world, it is scarcely mentioned that more than three-quarters of this cultivated area of 2,5 $\times 10^{6}$ ha consists of plots of less than 10 ha (Cátedra Caja Rural de Jaén, 2020; Junta de Andalucía. Consejería de Agricultura, Pesca y Desarrollo Rural, 2015). This high degree of fragmentation also occurs in Andalusia, where $60 \%$ of the national production is concentrated (Colombo and Villanueva, 2018). The majority of these producers are members of cooperative mills to which they sell their fruit. Few of them produce their own oil. A shift towards producing more quality olive oil instead of aiming to maximize the quantity is becoming eminent in Spain, and as a consequence, the availability of fresh undamaged fruit has come to the fore as a critical factor for many mills (Rallo et al., 2018). Evaluating the quality of the fruit is rapidly becoming standard procedure and experiments with automated assessment tools are under development (Puerto et al., 2015; Navarro Soto et al., 2018; Aguilera Puerto et al., 2019). The impact of this shift on the producer's side is straightforward: a better quality means a better price. Meanwhile, a growing number of independent small producers aim to produce their own 'high end' or 'Premium' oil. For them, the necessity to optimize the harvest conditions are even more important regardless of whether they produce their own oil or, as is more often the case, they bring their olives to a private mill where they are processed as a custom-made batch.

Despite the differences between both types of small producers, they are confronted with peculiar constraints. First of all, they are limited in resources when it comes to investing in specialized harvesting machinery or to contract expensive harvesting services. The absence of adequate technology makes the use of manual collection methods (manual beating, shaker combs, or branch shakers) with nets placed under the trees still widespread (Serrano et al., 2012). This traditional method entails the risks of damaging the fruit, be it by the dragging of the nets over the ground or by stepping on the fallen fruit during harvesting (Famiani et al., 2020). Secondly, the labor capacity consists very often of family members. This limited work capacity on the farm determines how long it will take to obtain enough fruit to carry out the transport. As a consequence, storage may be delayed by several days before this amount is reached. Besides, the Andalusian olive farmer who opts to produce his own oil in a private mill has to deal with the requirement of delivering a minimal quantity of various tons before the fruit will be processed as a separate batch.

These factors threaten the production of high-quality olive fruit. Fruit damaged during harvesting directly jeopardizes the quality of the processed oil, while prolonged storage in trailers means rapid deterioration due to the proliferation of fungi and bacteria. As a consequence, after being processed in the mill, only virgin olive oils which are not of optimal quality are produced, which irrevocably reduces their profitability (García and Yousfi, 2006).

Recently, a new type of harvesting device has come to the foreground as a possible solution for small producers to optimize their recollection. It basically consists of a manually displaceable structure with an inverted umbrella that can be placed around the trunk and a system to collect the fallen fruit into a box. Instead of trunk shakers, more economic branch shakers are used to detach to fruit. Various models already exist in the market (Bosco, Olitree, Crendon Machinery), of which some even have a motorized part to facilitate moving the device. Nevertheless, several problems in the handling of the device persist (access to the tree, excess of weight, handling of the boxes), while at the same time its efficiency has not been studied until recently. Plasquy et al. (2019) compared the efficiency of a prototype with the traditional recollection method with nets, contrasting different work crews, and the number of branch shakers used. The results showed the importance of the composition of the harvest crew and clarified that when the harvest was done by four operators, of which two used branch shakers, the efficiency of working with a MIU as compared to the use of nets was not significantly different.

To tackle the second major challenge, namely the avoidance of the detrimental process, cold storage of the fruit has been proposed as a possible solution, allowing for reasonable maintenance of its physiological integrity, without harming the quality of the extracted oils because it depends directly on the quality of the fruit from which it comes (Canet and García, 1999). However, besides a largescale experiment, the technique has not been implemented on an industrial level due to the logistic and infrastructural difficulties that arise when handling large quantities of fruit daily (García et al., 1996). The use of cold storage at the farm level has not been documented nor evaluated thus far. This work presents such a cooling room, designed to store up to $5000 \mathrm{~kg}$ at $5{ }^{\circ} \mathrm{C}$ at the farm and evaluates its effects on the quality of the fruit, taking into account the aforementioned harvesting methods.

\section{MATERIALS AND METHODS}

\subsection{Location and design}

The fruit for the experiment was harvested on a farm in Bollullos Par del Condado in 2017 (Huelva, Andalusia, Spain). The olive grove covers 8 ha and includes 1200 trees, primarily of the cultivars 'Arbequina', 'Picual', and 'Verdial'. The trees were planted between 2005 and 2007 at distances of $6 \times 7 \mathrm{~m}$ and irrigated according to a deficient regimen.

The 'Arbequina' fruit was collected in the second week of October (mean color index (CI): 34.5); the 'Picual' fruit in the first week of November (CI: 28.5); and the 'Verdial' fruit in the last week of November (CI: 20.81). To simultane- 
ously evaluate the effects of the collection and conservation methods on fruit quality, $40 \mathrm{~kg}$ of olives were harvested with each collection method, namely a Manual Inverted Umbrella (MIU), referred to as Recollection Method 1 (R1), and the traditional method with nets, Recollection Method 2 (R2). From this $40 \mathrm{~kg}$ set, half was randomly taken and placed in a refrigerated room at $5^{\circ} \mathrm{C}$, referred to as Storage Method 1 (S1); while the other half was stored indoors, but outside the refrigerator at room temperature, Storage Method 2 (S2), as is usually done with olives before processing. The physiological characteristics of the olives were evaluated at times: $0,4,8$, and 14 days of storage (ST).

The MIU was designed to catch and collect the olives into boxes, preventing them from touching the ground (Figure 1a). A detailed description of the device can be found in Plasquy et al. (2019). The boxes where the picked olives were collected have a capacity of $20 \mathrm{~kg}$, placed under the umbrella, and removed when full using a system of pulls and ropes. The harvesting team consisted of two operators who detached the fruit with branch shakers and two men who handled the MIU and the boxes. The traditional way of harvesting (R2) to which the R1 was compared, used nets that were placed under the tree (Figure 1b). Two operators with branch shakers stepped on the nets and moved around the tree to detach the fruit. Once picked, the nets with the fallen fruit were dragged to the next tree and spread open by two other men after which the operators continued to detach the fruit with the branch shakers. This continued until the nets became too heavy to displace them to the next tree. At that moment the collected olives were transferred into the same type of boxes used in R1.

The cooling room was installed in an existing outhouse on-site at the farm (Figure 1c). The existing construction measured $4.3 \times 4.4 \mathrm{~m}$ on the ground floor. The inclination
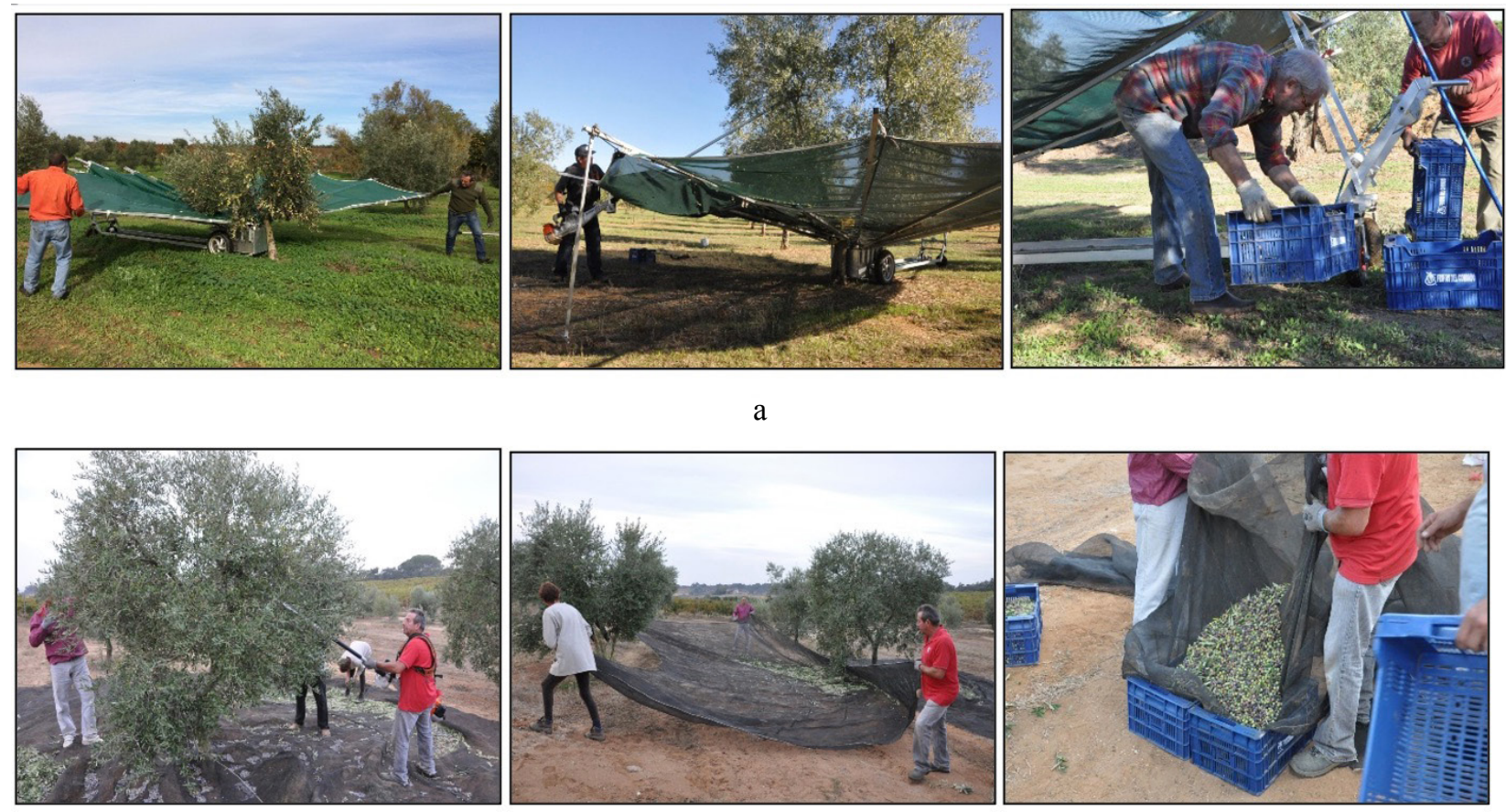

b
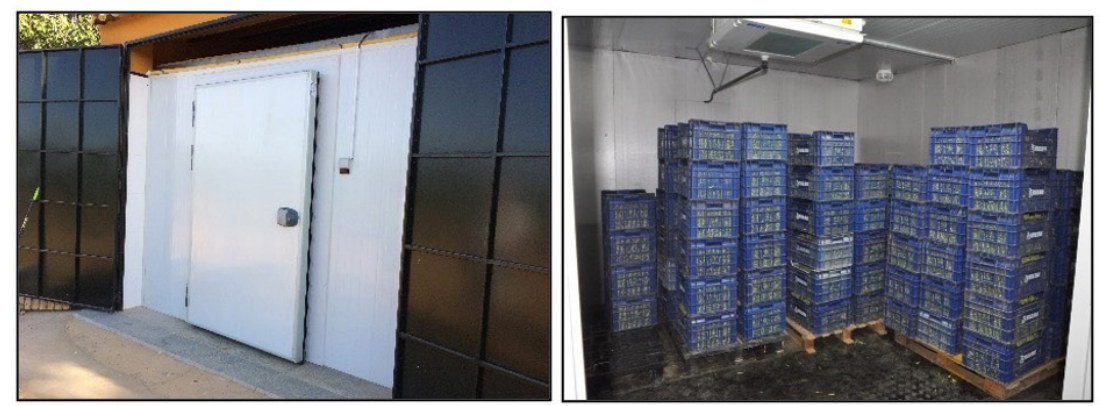

c

FIGURE 1. a. Harvesting with the use of the Manual Inverted Umbrella and branch shakers (R1); b. Conventional harvest with nets placed on the ground and using branch shakers (R2); c. Cooling room installation in a barn at the farm. 
of the roof served to install a ceiling at $2.5 \mathrm{~m}$, after which two separate spaces were created. Behind the existing barn gate of $3.0 \mathrm{~m}$ width, a separation wall was mounted with $10-\mathrm{cm}$ thick extruded polystyrene sandwich insulating panels and a cooling door of $1,2 \mathrm{~m}$ width. The inside walls and the ceiling were isolated with insulating panels of $10 \mathrm{~cm}$. The floor was covered with the same panels and finished with wooden boards of $2.5 \mathrm{~cm}(\mathrm{OSB})$ and a rubber protector. On the upper level a cold group was placed, formed by a compressor (EMBRACO, UNJ 9232) and the evaporator (LU-VE, SHDN 25-80) was mounted on the ceiling of the cooling room. A thermostat was mounted on the outside to have visual control of the inside temperature. The capacity of the cooling room amounted to $6.000 \mathrm{~kg}$. The system was able to keep the chamber at $5^{\circ} \mathrm{C}\left( \pm 1^{\circ} \mathrm{C}\right)$. To maintain this temperature, the compressor started every 5 to $10 \mathrm{~min}$ and ran for approximately $4 \mathrm{~min}$. The cost to install the cooling room amounted to $2.500 €$, including the purchase and installation of the refrigerating group by a technician, the isolation panels, the iron structure, and the finishing of the floor. The energy consumption amounted to $16 \mathrm{kWh}$, taking into account a consumption of $2 \mathrm{~kW}$ for the different motors present, working one-third of the time.

\subsection{Fruit characteristics}

\subsubsection{Incidence of decay}

The incidence of decayed fruit was quantified (bruised fruit or with visible fungal infection). Triplicate samples of 100 olives were randomly selected at the beginning of the experiment (Time 0 ) for each collection method and were kept in S1 or S2 throughout the storage period, with the same samples being used to quantify this parameter on each sampling date.

\subsubsection{Weight loss}

Tetraplicate samples of 100 olives were randomly selected at the beginning of the experiment (Time 0) for each recollection method and placed in four plastic baskets which were individually weighed on each sampling date with a precision of $0.1 \mathrm{mg}$ and kept in S1 or S2 throughout the storage period.

\subsubsection{Skin color and firmness}

The color of the fruit was determined on the equatorial zone of the same 100 olives of each variety and each one of the 4 treatments, on each sampling date, using a Minolta CR400 (Minolta Camera Co., Osaka, Japan) chroma-meter with a measuring area of $8 \mathrm{~mm}$ in diameter, diffuse illumination and a viewing angle of $0^{\circ}$. The CIE L*a*b* color notation system was applied to determine the parameters $L^{*}, a^{*}$ and $b^{*}$; where $L^{*}$ indicates lightness, $a^{*}$ means the color axis from green to red, and $\mathrm{b}^{*}$ the blue-yellow tone. Using these parameters, a color index was calculated according to the formula: $\mathrm{CI}=\mathrm{L}^{*}\left(\mathrm{~b}^{*}-\mathrm{a}^{*}\right) / 100$, which is strongly correlated to olive de-greening during cold storage (Castellano et al., 1993).

Initially, 100 olives were randomly selected for each of the 4 treatments and kept in S1 or S2 throughout the storage period in plastic baskets, using the same replicate of 100 olives in each sample. Firmness measurements were taken randomly in the equatorial zone of each olive, using a Zwick 3300 non-destructive densimeter (Zwick $\mathrm{GmbH} \&$ Co., Ulm, Germany) with the pressure of a 5 $\mathrm{mm}$ diameter disk. The results were expressed in $\mathrm{N}$.

\subsubsection{Respiration rate and ethylene production}

Triplicates of $30 \mathrm{~g}$ olives were randomly taken from the $20 \mathrm{~kg}$ box of each treatment and placed in $125-\mathrm{mL}$ open glass jars at $20^{\circ} \mathrm{C}$ for $2 \mathrm{~h}$. Subsequently, they were hermetically sealed for $3 \mathrm{~h}$ at the same temperature. The $\mathrm{CO}_{2}$ contents of the headspace of these jars were determined with a G100 portable gas analyzer (Geotechnical Instrument Ltd., Leamington Spa, UK) and the ethylene content was subsequently evaluated using an ICA portable ethylene analyzer (International Controlled Atmosphere Ltd., Paddock Wood, UK). $\mathrm{CO}_{2}$ and ethylene concentrations were expressed in $\mathrm{mL} / \mathrm{kg} \mathrm{h}$ and $\mu \mathrm{L} / \mathrm{kg} \mathrm{h}$, respectively.

\subsection{Statistical analysis}

For each cultivar, decay incidence, weight loss, firmness, respiration rate, and ethylene production were analyzed by one-way ANOVA to determine the effect of the four treatments at each storage time (ST). The same variables were analyzed by two-way ANOVA to determine the effect of the treatments and the ST, and by three-way ANOVA to detect the effect of the three independent factors (four ST, two $\mathrm{R}$, and two $\mathrm{S})$. When a significant $(\mathrm{P}<0.05)$ effect due to treatment or ST was detected, the Tuckey test was applied to distinguish mean values $(\mathrm{P}<0.05)$.

The parameters of skin color did not show normal distributions and were not studied using parametric tests. Each value was identified by the mean value of 100 replicates \pm standard deviation (SD). The nonlinear curve fit of the histograms of the IC (OriginPro 9.1.0, OriginLab Corp. Northampton, USA) are presented for 0 and 14 storage days in the four treatments tested (two R and two S) in each cultivar.

\section{RESULTS}

\subsection{Incidence of decay}

In all the studied cultivars both the ST and the use of different treatments affected decay incidence in one way 
at least, which was very significant $(\mathrm{P}<0.01)$, considering all the ST and each sampling date independently for this period (Figure 1). During the progress of the ST, the values for this variable increased differently according to the treatment applied. The recollection method turned out to be decisive for the changes in decay incidence in the stored fruit. Thus, the treatments using the R1 showed significantly lower decay than the harvest using nets, regardless of the storage temperature or the cultivar tested. The cold storage also showed an effect on 'Arbequina' and 'Picual' cultivars for this parameter. 'Verdial' olives presented no significant differences due to the different storage temperatures. However, systematically, the treatments with cold storage obtained lower decay values than their counterparts. The interaction between the $\mathrm{R}$ and the $\mathrm{S}$ only caused an effect on 'Arbequina' olives for this variable. During the ST decay incidence significantly increased in all the treatments and cultivars. However, each variety showed different behavior in this period. Whereas in 'Arbequina' fruit the differences between the treatments R2S2 and the rest in- creased throughout this period. The differences among the rest of combined treatments decreased and were not significant from the third sampling date (day 8). Similarly, the differences in decay incidence in 'Picual' olives between $\mathrm{R} 2 \mathrm{~S} 2$ and the other treatments increased over the examined storage time. The three lasting treatments stayed akin with respect to the decay incidence until R1S1 exhibited the significantly lowest values for this parameter at day 14 . In contrast, 'Verdial' fruit was affected by $\mathrm{R}$ throughout the entire storage period, except for the last sampling date (day 14), when, as for 'Picual' olives, the treatment R1S1 showed the significantly lowest values for this parameter.

\subsection{Weight loss}

The effect on this parameter was extremely significant for the three varieties $(\mathrm{P}<0.001)$ according to the treatments applied, the progress of storage time, and the interactions of both factors (Table 1). As in the case of decay incidence, the values for this variable increased differently

TABLE 1. Weight loss (\%) of olive fruit under four different treatments (T) with two different collection methods (R1: Manual Inverted Umbrella; R2: nets), and two storage methods ( $\mathrm{S} 1: 5^{\circ} \mathrm{C}$; S2: room temperature), during storage time (ST): 0, 4, 8, 14 days for 'Arbequina', 'Picual' and 'Verdial' cultivars. Each value indicates the mean value of 4 replicates \pm standard deviation.

\begin{tabular}{|c|c|c|c|c|c|}
\hline \multirow{2}{*}{ DAY } & \multirow{2}{*}{$\mathbf{R}$} & \multirow{2}{*}{$\mathbf{S}$} & \multicolumn{3}{|c|}{ Weight Loss (\%) } \\
\hline & & & ARBEQUINA & PICUAL & VERDIAL \\
\hline \multirow[t]{4}{*}{0} & 1 & 1 & $0.0 \pm 0.0$ & $0.0 \pm 0.0$ & $0.0 \pm 0.0$ \\
\hline & & 2 & $0.0 \pm 0.0$ & $0.0 \pm 0.0$ & $0.0 \pm 0.0$ \\
\hline & 2 & 1 & $0.0 \pm 0.0$ & $0.0 \pm 0.0$ & $0.0 \pm 0.0$ \\
\hline & & 2 & $0.0 \pm 0.0$ & $0.0 \pm 0.0$ & $0.0 \pm 0.0$ \\
\hline \multirow[t]{4}{*}{4} & 1 & 1 & $0.4 \pm 0.1 b^{*}$ & $0.6 \pm 0.1 \mathrm{~b}$ & $0.3 \pm 0.1 \mathrm{~b}$ \\
\hline & & 2 & $0.9 \pm 0.0 \mathrm{a}$ & $2.6 \pm 0.4 \mathrm{a}$ & $1.8 \pm 0.7 \mathrm{a}$ \\
\hline & 2 & 1 & $0.4 \pm 0.1 \mathrm{~b}$ & $0.5 \pm 0.1 b$ & $0.5 \pm 0.1 \mathrm{~b}$ \\
\hline & & 2 & $0.9 \pm 0.0 \mathrm{a}$ & $2.2 \pm 0.1 \mathrm{a}$ & $1.3 \pm 0.2 \mathrm{a}$ \\
\hline \multirow[t]{4}{*}{8} & 1 & 1 & $0.8 \pm 0.2 \mathrm{bc}$ & $1.2 \pm 0.3 b$ & $0.6 \pm 0.1 \mathrm{c}$ \\
\hline & & 2 & $1.5 \pm 0.4 \mathrm{a}$ & $4.6 \pm 0.9 \mathrm{a}$ & $3.1 \pm 1.3 \mathrm{a}$ \\
\hline & 2 & 1 & $0.7 \pm 0.1 \mathrm{c}$ & $1.0 \pm 0.2 \mathrm{~b}$ & $1.0 \pm 0.2 \mathrm{c}$ \\
\hline & & 2 & $1.3 \pm 0.2 \mathrm{ab}$ & $4.1 \pm 0.3 \mathrm{a}$ & $2.2 \pm 0.3 \mathrm{~b}$ \\
\hline \multirow[t]{4}{*}{14} & 1 & 1 & $1.5 \pm 0.4 \mathrm{~b}$ & $2.0 \pm 0.5 b$ & $1.0 \pm 0.1 \mathrm{c}$ \\
\hline & & 2 & $3.1 \pm 0.8 \mathrm{a}$ & $7.3 \pm 1.4 \mathrm{a}$ & $5.0 \pm 2.2 \mathrm{a}$ \\
\hline & 2 & 1 & $1.3 \pm 0.2 \mathrm{~b}$ & $1.6 \pm 0.2 b$ & $1.7 \pm 0.3 \mathrm{c}$ \\
\hline & & 2 & $2.6 \pm 0.3 \mathrm{a}$ & $6.4 \pm 0.7 \mathrm{a}$ & $3.5 \pm 0.6 \mathrm{~b}$ \\
\hline effect of ST & & 0.000 & 0.000 & 0.000 & \\
\hline effect of T & & 0.000 & 0.000 & 0.000 & \\
\hline effect of ST x T & & 0.000 & 0.000 & 0.000 & \\
\hline effect of R & & 0.076 & 0.081 & 0.268 & \\
\hline effect of S & & 0.000 & 0.000 & 0.000 & \\
\hline effect of ST $x$ R & & 0.361 & 0.352 & 0.876 & \\
\hline effect of ST x S & & 0.000 & 0.000 & 0.000 & \\
\hline effect of R x S & & 0.579 & 0.254 & 0.066 & \\
\hline effect of ST $x$ R $x$ S & & 0.876 & 0.903 & 0.170 & \\
\hline
\end{tabular}

* For each storage day, the values for different combinations of treatments followed by different lowercase letters are significantly different according to the Tukey test $(\mathrm{P}<0.05)$. Absence of letter means no significant effect due to treatment according to one-way ANOVA $(\mathrm{P}<0.05)$. 
6 E. Plasquy, G. Blanco-Roldán, M.C. Florido and J.M. García

TABLE 2. Skin color (L*, $a^{*}, b^{*}$, IC values) for 'Arbequina', 'Picual' and 'Verdial' cultivars, collected with two different collection methods (R1: Manual Inverted Umbrella; R2: nets) and two storage methods (S1: $5^{\circ} \mathrm{C}$; S2: room temperature) during storage time $(0,4,8,14$ days). Each value indicates mean value $(\mathrm{N}=100) \pm \mathrm{SD}$.

\begin{tabular}{|c|c|c|c|c|c|c|c|}
\hline CULTIVAR & DAY & $\mathbf{R}$ & $\mathbf{S}$ & $\mathbf{L}$ & $\mathbf{a}$ & b & IC \\
\hline \multirow[t]{16}{*}{ ARBEQUINA } & 0 & 1 & 1 & $65 \pm 8$ & $-15 \pm 8$ & $36 \pm 10$ & $34 \pm 12$ \\
\hline & & & 2 & $64 \pm 8$ & $-14 \pm 9$ & $35 \pm 10$ & $33 \pm 13$ \\
\hline & & 2 & 1 & $65 \pm 6$ & $-16 \pm 7$ & $38 \pm 8$ & $36 \pm 10$ \\
\hline & & & 2 & $64 \pm 8$ & $-15 \pm 9$ & $38 \pm 10$ & $35 \pm 13$ \\
\hline & 4 & 1 & 1 & $64 \pm 9$ & $-14 \pm 9$ & $37 \pm 10$ & $34 \pm 13$ \\
\hline & & & 2 & $62 \pm 9$ & $-13 \pm 11$ & $34 \pm 11$ & $31 \pm 14$ \\
\hline & & 2 & 1 & $64 \pm 7$ & $-15 \pm 8$ & $38 \pm 8$ & $35 \pm 10$ \\
\hline & & & 2 & $64 \pm 7$ & $-16 \pm 8$ & $39 \pm 9$ & $36 \pm 12$ \\
\hline & 8 & 1 & 1 & $63 \pm 9$ & $-13 \pm 9$ & $36 \pm 10$ & $32 \pm 12$ \\
\hline & & & 2 & $60 \pm 11$ & $-10 \pm 13$ & $32 \pm 13$ & $28 \pm 16$ \\
\hline & & 2 & 1 & $64 \pm 7$ & $-15 \pm 8$ & $39 \pm 8$ & $36 \pm 11$ \\
\hline & & & 2 & $62 \pm 9$ & $-15 \pm 9$ & $38 \pm 10$ & $34 \pm 13$ \\
\hline & 14 & 1 & 1 & $63 \pm 9$ & $-14 \pm 9$ & $37 \pm 11$ & $34 \pm 13$ \\
\hline & & & 2 & $49 \pm 11$ & $1 \pm 12$ & $22 \pm 13$ & $13 \pm 15$ \\
\hline & & 2 & 1 & $63 \pm 8$ & $-15 \pm 9$ & $39 \pm 9$ & $35 \pm 12$ \\
\hline & & & 2 & $52 \pm 10$ & $-2 \pm 11$ & $27 \pm 11$ & $17 \pm 13$ \\
\hline \multirow[t]{16}{*}{ PICUAL } & 0 & 1 & 1 & $62 \pm 11$ & $-9 \pm 12$ & $33 \pm 11$ & $28 \pm 15$ \\
\hline & & & 2 & $62 \pm 11$ & $-9 \pm 12$ & $33 \pm 11$ & $28 \pm 15$ \\
\hline & & 2 & 1 & $60 \pm 11$ & $-10 \pm 13$ & $34 \pm 12$ & $29 \pm 15$ \\
\hline & & & 2 & $60 \pm 11$ & $-10 \pm 13$ & $34 \pm 12$ & $29 \pm 15$ \\
\hline & 4 & 1 & 1 & $59 \pm 13$ & $-7 \pm 15$ & $31 \pm 14$ & $26 \pm 17$ \\
\hline & & & 2 & $56 \pm 15$ & $-5 \pm 16$ & $27 \pm 15$ & $22 \pm 19$ \\
\hline & & 2 & 1 & $59 \pm 13$ & $-9 \pm 15$ & $33 \pm 13$ & $28 \pm 17$ \\
\hline & & & 2 & $57 \pm 14$ & $-7 \pm 15$ & $29 \pm 14$ & $24 \pm 18$ \\
\hline & 8 & 1 & 1 & $59 \pm 14$ & $-8 \pm 15$ & $31 \pm 14$ & $26 \pm 18$ \\
\hline & & & 2 & $51 \pm 16$ & $-2 \pm 16$ & $23 \pm 16$ & $18 \pm 19$ \\
\hline & & 2 & 1 & $56 \pm 14$ & $-6 \pm 16$ & $31 \pm 15$ & $25 \pm 19$ \\
\hline & & & 2 & $52 \pm 16$ & $-3 \pm 16$ & $24 \pm 15$ & $19 \pm 19$ \\
\hline & 14 & 1 & 1 & $56 \pm 15$ & $-5 \pm 16$ & $29 \pm 15$ & $23 \pm 19$ \\
\hline & & & 2 & $44 \pm 12$ & $2 \pm 10$ & $18 \pm 11$ & $10 \pm 13$ \\
\hline & & 2 & 1 & $55 \pm 15$ & $-5 \pm 17$ & $30 \pm 16$ & $23 \pm 20$ \\
\hline & & & 2 & $49 \pm 16$ & $-1 \pm 15$ & $22 \pm 16$ & $16 \pm 18$ \\
\hline \multirow[t]{16}{*}{ VERDIAL } & 0 & 1 & 1 & $60 \pm 11$ & $-4 \pm 18$ & $28 \pm 15$ & $21 \pm 19$ \\
\hline & & & 2 & $60 \pm 11$ & $-4 \pm 17$ & $28 \pm 15$ & $21 \pm 7$ \\
\hline & & 2 & 1 & $60 \pm 11$ & $'-4 \pm 17$ & $28 \pm 15$ & $21 \pm 19$ \\
\hline & & & 2 & $59 \pm 11$ & $-4 \pm 17$ & $11 \pm 0$ & $21 \pm 19$ \\
\hline & 4 & 1 & 1 & $59 \pm 12$ & $-4 \pm 18$ & $28 \pm 15$ & $21 \pm 19$ \\
\hline & & & 2 & $54 \pm 14$ & $-3 \pm 13$ & $24 \pm 13$ & $15 \pm 13$ \\
\hline & & 2 & 1 & $58 \pm 12$ & $-4 \pm 16$ & $28 \pm 15$ & $21 \pm 19$ \\
\hline & & & 2 & $57 \pm 13$ & $-4 \pm 16$ & $26 \pm 14$ & $18 \pm 16$ \\
\hline & 8 & 1 & 1 & $59 \pm 12$ & $-6 \pm 14$ & $27 \pm 15$ & $20 \pm 15$ \\
\hline & & & 2 & $50 \pm 15$ & $-3 \pm 12$ & $15 \pm 8$ & $9 \pm 8$ \\
\hline & & 2 & 1 & $57 \pm 13$ & $-6 \pm 16$ & $30 \pm 15$ & $20 \pm 13$ \\
\hline & & & 2 & $53 \pm 14$ & $-6 \pm 15$ & $18 \pm 10$ & $14 \pm 13$ \\
\hline & 14 & 1 & 1 & $58 \pm 12$ & $-4 \pm 18$ & $31 \pm 11$ & $21 \pm 16$ \\
\hline & & & 2 & $44 \pm 13$ & $8 \pm 14$ & $14 \pm 13$ & $5 \pm 14$ \\
\hline & & 2 & 1 & $56 \pm 14$ & $-6 \pm 14$ & $28 \pm 15$ & $20 \pm 17$ \\
\hline & & & 2 & $47 \pm 14$ & $6 \pm 12$ & $16 \pm 13$ & $7 \pm 13$ \\
\hline
\end{tabular}


during storage according to the combination of treatments applied. However, for this parameter, the storage temperature was the only factor that exerted a significant effect on the weight loss of the fruit, regardless of the cultivar tested. Cold storage significantly delayed the increase in this parameter during storage and this effect was increased significantly as the storage time became greater.

\subsection{Skin color}

According to chromatic values ( $\mathrm{L}^{*}, \mathrm{a}^{*}$ and $\mathrm{b}^{*}$ ) cold storage delayed fruit ripening. This effect was most evident in the olives, 'Picual' and 'Verdial', which exhibited similar variations in these chromatic parameters from the second sampling date after 4 storage days, and then the differences increased compared to the cold-stored ones, which only showed slight differences from the initial values (Table 2). The 'Arbequina' olives maintained similar color parameters over 8 days of storage, regardless of the harvest or storage methods. However, after 14 days of storage, the olives stored under ambient conditions presented obvious changes in these parameters. While $\mathrm{L}^{*}$ and $\mathrm{b}^{*}$ values decreased, $\mathrm{a}^{*}$ increased. This means that the skin of this fruit was darker, red and blue and less shiny, green and yellow. Consequently, these olives exhibited a darker purple (red + blue) skin color than those stored at $5{ }^{\circ} \mathrm{C}$.

The non-linear curve fits of the CI histogram values obtained from the different treatments in the three cultivars tested after 0 and 14 storage days showed that during the storage period the fruit was separated into three groups (Figures 2, $3,4)$. This three-modal profile evidenced that these distributions cannot be statistically evaluated by parametrical tests to know whether the effect of the different factors is significant. However, these histograms showed clear evidence that after 14 days of storage, the treatments kept at ambient temperature, regardless of the method used for harvesting, exhibited a higher frequency in the group with the lowest values for this parameter; whereas the cold-stored ones maintained higher frequency values in the group with the highest values for this chromatic formula. As CI diminished according to the progression of fruit ripening, it seems clear that the use of cold storage delayed this process.

\subsection{Firmness}

Similarly, as in the cases of weight loss and incidence of decay, the fruit of the 'Picual' and 'Verdial' cultivars tested showed similar behavior in changes in firmness, and were affected in an extremely significant way by the treatments applied, storage time, and interactions between these two factors. In the case of 'Arbequina' the effect of the treatment was only significant at day 14. (Table 3). All the fruit exhibited a decrease in the firmness parameter during storage time, but it was more evident in the fruit stored at ambient temperature, regardless of the method
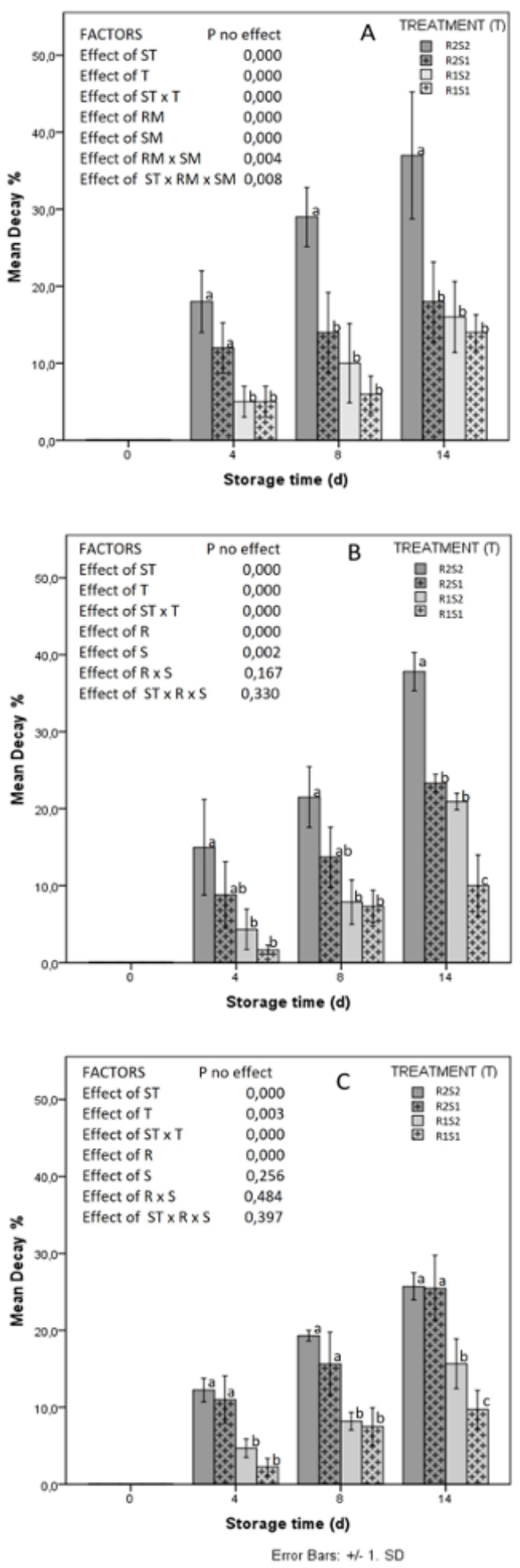

FIGURE 2. Decay incidence (\%) of olive fruit under four different treatments $(\mathrm{T})$ with two different collection methods (R1: Manual Inverted Umbrella; R2: nets) and two storage methods (S1: $5^{\circ} \mathrm{C}$; S2: room temperature) during storage time (ST: $0,4,8,14$ days) for 'Arbequina' (A), 'Picual' (B) and 'Verdial' (C) cultivars. Each point indicates the mean value (bar) $\pm \mathrm{SD}$ (error bar) of 3 replicates. In each cultivar and each ST the bars with different lowercase letters are statistically different according to the Tuckey test $(\mathrm{P}<0.05)$. 
TABLE 3. Firmness of 'Arbequina', 'Picual' and 'Verdial' cultivars, collected with two different collection methods (R1: Manual Inverted Umbrella; R2: nets) and two storage methods (S1: $5^{\circ} \mathrm{C}$; S2: room temperature) during storage time (ST): 0, 4, 8, 14 days. Each value indicates mean value $(\mathrm{N}=100) \pm \mathrm{SD}$.

\begin{tabular}{|c|c|c|c|c|c|}
\hline \multirow{2}{*}{ DAY } & \multirow{2}{*}{$\mathbf{R}$} & \multirow{2}{*}{$\mathbf{S}$} & \multicolumn{3}{|c|}{ Firmness (N) } \\
\hline & & & ARBEQUINA & PICUAL & VERDIAL \\
\hline \multirow[t]{4}{*}{0} & 1 & 1 & $46 \pm 3$ & $44 \pm 5$ & $46 \pm 2$ \\
\hline & & 2 & $46 \pm 3$ & $44 \pm 5$ & $45 \pm 3$ \\
\hline & 2 & 1 & $46 \pm 3$ & $44 \pm 5$ & $45 \pm 3$ \\
\hline & & 2 & $46 \pm 3$ & $44 \pm 5$ & $44 \pm 4$ \\
\hline \multirow[t]{4}{*}{4} & 1 & 1 & $44 \pm 3$ & $44 \pm 4 a^{*}$ & $42 \pm 4 \mathrm{ab}$ \\
\hline & & 2 & $43 \pm 3$ & $41 \pm 4 b$ & $41 \pm 2 b$ \\
\hline & 2 & 1 & $45 \pm 2$ & $44 \pm 5 a$ & $43 \pm 4 \mathrm{a}$ \\
\hline & & 2 & $43 \pm 3$ & $41 \pm 4 b$ & $38 \pm 3 \mathrm{c}$ \\
\hline \multirow[t]{4}{*}{8} & 1 & 1 & $43 \pm 3$ & $43 \pm 5 \mathrm{a}$ & $43 \pm 5 \mathrm{a}$ \\
\hline & & 2 & $40 \pm 3$ & $35 \pm 4 b$ & $41 \pm 3 b$ \\
\hline & 2 & 1 & $42 \pm 2$ & $43 \pm 5 \mathrm{a}$ & $44 \pm 4 \mathrm{a}$ \\
\hline & & 2 & $41 \pm 2$ & $39 \pm 5 b$ & $40 \pm 4 b$ \\
\hline \multirow[t]{4}{*}{14} & 1 & 1 & $42 \pm 3 a$ & $42 \pm 6 \mathrm{a}$ & $44 \pm 3 \mathrm{a}$ \\
\hline & & 2 & $36 \pm 3 b$ & $30 \pm 8 b$ & $40 \pm 6 b$ \\
\hline & 2 & 1 & $42 \pm 3 \mathrm{a}$ & $43 \pm 6 a$ & $42 \pm 4 \mathrm{ab}$ \\
\hline & & 2 & $36 \pm 3 b$ & $35 \pm 6 b$ & $39 \pm 6 b$ \\
\hline effect of ST & & 0.000 & 0.000 & 0.000 & \\
\hline effect of T & & 0.957 & 0.000 & 0.000 & \\
\hline effect of ST x T & & 0.000 & 0.000 & 0.000 & \\
\hline effect of R & & 0.034 & 0.000 & 0.488 & \\
\hline effect of S & & 0.000 & 0.000 & 0.000 & \\
\hline effect of ST $x$ R & & 0.786 & 0.000 & 0.238 & \\
\hline effect of ST x S & & 0.006 & 0.001 & 0.000 & \\
\hline effect of $\mathrm{R} \times \mathrm{S}$ & 0.786 & 0.000 & 0.238 & & \\
\hline effect of ST $x$ R X S & 0.006 & 0.001 & 0.000 & & \\
\hline
\end{tabular}

* For each storage day, the values for different combinations of treatments followed by different lowercase letters are significantly different according to the Tukey test $(\mathrm{P}<0.05)$. Absence of letter means no significant effect due to treatment according to one-way ANOVA $(\mathrm{P}<0.05)$.

used for harvesting. The firmness of 'Verdial' fruit was not affected by the R. Both 'Arbequina' and 'Picual' fruit firmness harvested by R1 showed significantly higher mean values for this parameter than the $\mathrm{R} 2$ harvested fruit. Cold storage allowed for maintaining significantly higher mean values for firmness in the fruit of the three cultivars. As storage time progressed, the effect of factors $\mathrm{R}$ and $\mathrm{S}$ increased their effects on fruit firmness. The 'Arbequina' and 'Verdial' olives did not show a significant effect of $\mathrm{R}$ or storage time. However, both cultivars, as well as 'Picual' were significantly affected by the combined effect of the three factors (ST, R, and S).

\subsection{Respiration rate and ethylene production}

The production of $\mathrm{CO}_{2}$ followed the same profile as the other studied parameters, showing a highly significant effect due to storage time, the combination of treatments applied, and the interaction of both of them (Table 4). Storage method resulted in the most important cause of variability for this parameter for the three varieties considered. This effect increased with the progression of the storage time. The fruit stored at $5{ }^{\circ} \mathrm{C}$ showed a significantly higher respiration rate than the one stored at ambient temperature when this parameter was tested at $20^{\circ} \mathrm{C}$. This effect increased 
TABLE 4. Respiration ( $\mathrm{mLCO} 2 / \mathrm{kg} \mathrm{h})$ and Ethylene production $(\mathrm{uL} / \mathrm{kg} \mathrm{h})$ of 'Arbequina', 'Picual' and 'Verdial' cultivars collected with two collection methods (R1: Manual Inverted Umbrella; R2: nets) and two storage methods ( $\mathrm{S} 1: 5^{\circ} \mathrm{C}$; $\mathrm{S} 2$ : room temperature) during storage time $(0,4,8,14$ days). Each value indicates the mean value of 3 replicates $\pm \mathrm{SD}$.

\begin{tabular}{|c|c|c|c|c|c|c|c|c|}
\hline \multirow{2}{*}{ DAY } & \multirow{2}{*}{$\mathbf{R}$} & \multirow{2}{*}{$\mathbf{S}$} & \multicolumn{2}{|c|}{ ARBEQUINA } & \multicolumn{2}{|c|}{ PICUAL } & \multicolumn{2}{|c|}{ VERDIAL } \\
\hline & & & $\mathrm{CO}_{2}$ & Ethylene & $\mathrm{CO}_{2}$ & Ethylene & $\mathrm{CO}_{2}$ & Ethylene \\
\hline \multirow[t]{4}{*}{0} & 1 & 1 & $263 \pm 62$ & $10 \pm 1$ & $308 \pm 17$ & $19 \pm 2 b$ & $653 \pm 126$ & $19 \pm 2$ \\
\hline & & 2 & $263 \pm 62$ & $10 \pm 1$ & $308 \pm 17$ & $19 \pm 2 b$ & $653 \pm 126$ & $19 \pm 2$ \\
\hline & 2 & 1 & $343 \pm 12$ & $22 \pm 7$ & $283 \pm 94$ & $39 \pm 5 \mathrm{a}$ & $488 \pm 153$ & $34 \pm 14$ \\
\hline & & 2 & $343 \pm 12$ & $22 \pm 7$ & $283 \pm 94$ & $39 \pm 5 a$ & $488 \pm 153$ & $34 \pm 14$ \\
\hline \multirow[t]{4}{*}{4} & 1 & 1 & $150 \pm 45$ & $11 \pm 1$ & $163 \pm 53 b$ & $18 \pm 1 b$ & $405 \pm 63 \mathrm{a}$ & $10 \pm 1$ \\
\hline & & 2 & $128 \pm 14$ & $11 \pm 2$ & $226 \pm 8 \mathrm{~b}$ & $21 \pm 1 b$ & $150 \pm 50 \mathrm{~b}$ & $11 \pm 0$ \\
\hline & 2 & 1 & $233 \pm 100$ & $16 \pm 2$ & $442 \pm 42 \mathrm{a}$ & $24 \pm 8 \mathrm{ab}$ & $383 \pm 105 \mathrm{a}$ & $15 \pm 5$ \\
\hline & & 2 & $214 \pm 76$ & $21 \pm 8$ & $188 \pm 47 b$ & $45 \pm 16 \mathrm{a}$ & $138 \pm 21 b$ & $15 \pm 0$ \\
\hline \multirow[t]{4}{*}{8} & 1 & 1 & $78 \pm 11$ & $19 \pm 1$ & $324 \pm 111 \mathrm{a}$ & $16 \pm 2 c$ & $354 \pm 23 \mathrm{a}$ & $7 \pm 1 \mathrm{c}$ \\
\hline & & 2 & $88 \pm 30$ & $20 \pm 3$ & $117 \pm 40 \mathrm{~b}$ & $20 \pm 2 c$ & $61 \pm 11 \mathrm{c}$ & $24 \pm 4 \mathrm{a}$ \\
\hline & 2 & 1 & $156 \pm 50$ & $22 \pm 6$ & $371 \pm 34 \mathrm{a}$ & $48 \pm 0 b$ & $300 \pm 42 \mathrm{a}$ & $15 \pm 4 b$ \\
\hline & & 2 & $118 \pm 23$ & $25 \pm 7$ & $45 \pm 1 b$ & $86 \pm 4 a$ & $190 \pm 5 \mathrm{~b}$ & $30 \pm 1 \mathrm{a}$ \\
\hline \multirow[t]{4}{*}{14} & 1 & 1 & $291 \pm 20 \mathrm{a}^{*}$ & $14 \pm 1$ & $186 \pm 27$ & $11 \pm 2 b$ & $381 \pm 50 \mathrm{a}$ & $11 \pm 1 \mathrm{c}$ \\
\hline & & 2 & $137 \pm 31 \mathrm{~b}$ & $21 \pm 3$ & $152 \pm 63$ & $34 \pm 8 \mathrm{a}$ & $181 \pm 56 b$ & $46 \pm 9 b$ \\
\hline & 2 & 1 & $378 \pm 55 \mathrm{a}$ & $22 \pm 2$ & $160 \pm 56$ & $21 \pm 8 \mathrm{ab}$ & $426 \pm 19 a$ & $16 \pm 3 \mathrm{c}$ \\
\hline & & 2 & $84 \pm 5 b$ & $26 \pm 8$ & $136 \pm 31$ & $39 \pm 10 \mathrm{a}$ & $272 \pm 10 b$ & $100 \pm 18 \mathrm{a}$ \\
\hline effect of ST & 0.000 & 0.001 & 0.000 & 0.000 & 0.000 & 0.000 & & \\
\hline effect of T & 0.000 & 0.000 & 0.000 & 0.000 & 0.000 & 0.000 & & \\
\hline effect of ST x T & 0.000 & 0.469 & 0.000 & 0.000 & 0.003 & 0.000 & & \\
\hline effect of R & 0.000 & 0.000 & 0.343 & 0.000 & 0.420 & 0.000 & & \\
\hline effect of S & 0.000 & 0.063 & 0.000 & 0.000 & 0.000 & 0.000 & & \\
\hline effect of ST $x$ R & 0.279 & 0.170 & 0.007 & 0.000 & 0.007 & 0.001 & & \\
\hline effect of ST x S & 0.000 & 0.585 & 0.000 & 0.001 & 0.004 & 0.000 & & \\
\hline effect of R x S & 0.094 & 0.742 & 0.002 & 0.002 & 0.211 & 0.014 & & \\
\hline effect of ST $x$ R $x$ S & 0.218 & 0.669 & 0.003 & 0.001 & 0.497 & 0.000 & & \\
\hline
\end{tabular}

* Each storage day, for each variable the values for different treatments followed by different lowercase letters are significantly different according to the Tukey test $(\mathrm{P}<0.05)$. Absence of letter means no significant effect due to treatment according to one-way ANOVA $(\mathrm{P}<0.05)$.

with the progression of storage time. Only 'Arbequina' olives showed a significant effect due to $\mathrm{R}$, which did not significantly interact with the progression of storage time. From the beginning of the storage period, the fruit harvested with R2 exhibited a higher respiration rate than the others. 'Picual' olives turned out to be especially sensitive to the combinations of the factors tested, but was not affected by the individual action of the different $R$.

All the varieties were affected at least very significantly $(\mathrm{P}<0.01)$ in the amount of synthesized ethylene due to storage time and the four different treatments applied. Except for 'Arbequina' olives, which did not show significant differences in the amounts of synthesized ethylene induced by the combination of the effect due to storage time and treatment, the rest of the varieties were also affected by the interaction of these two factors. The recollection was mainly responsible for these effects. For all the varieties tested, the fruit harvested with nets showed higher amounts of synthesized ethylene than when picked with MIU. The storage determined an extremely significant effect on the amount of synthesized ethylene $(\mathrm{P}<0.001)$ in 'Picual' and 'Verdial' olives, while in 'Arbequina' olives this effect was very near to being significant $(\mathrm{P}<0.063)$. 'Picual' and 'Verdial' fruit was also, at least, significantly $(\mathrm{P}<0.05)$ affected 

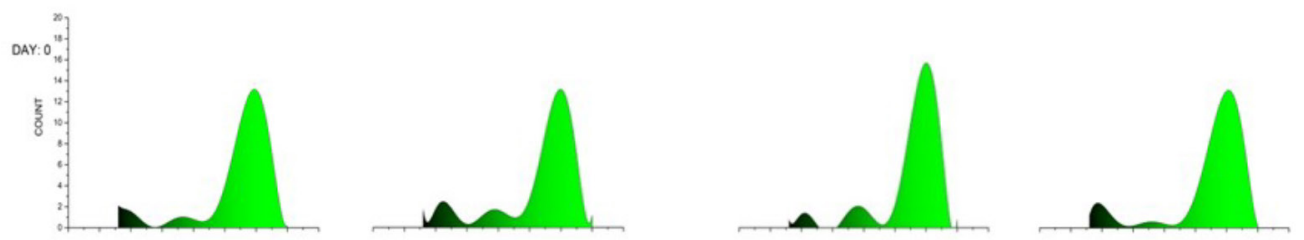

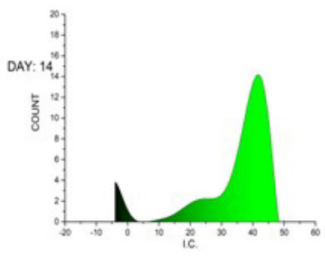

R1S1
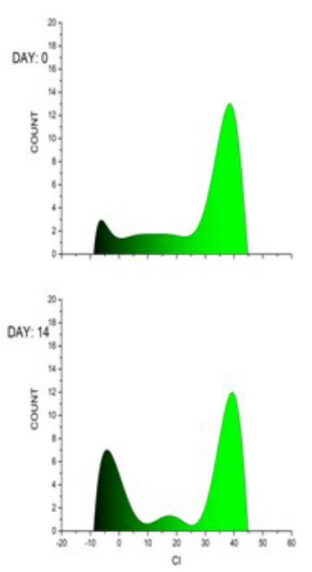

R1S1
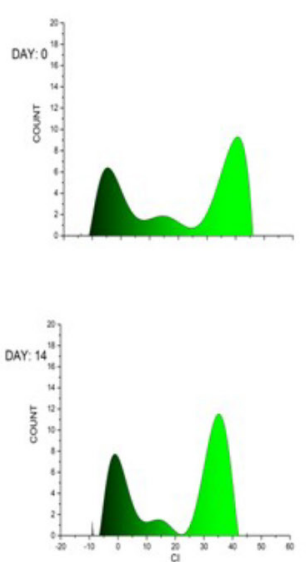

R1S1

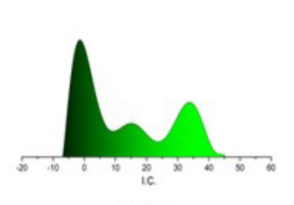

R1S2
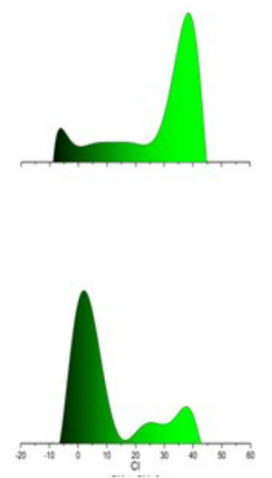

R1S2
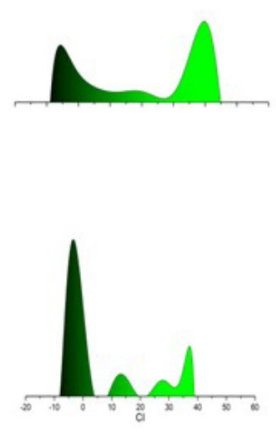

R1S2
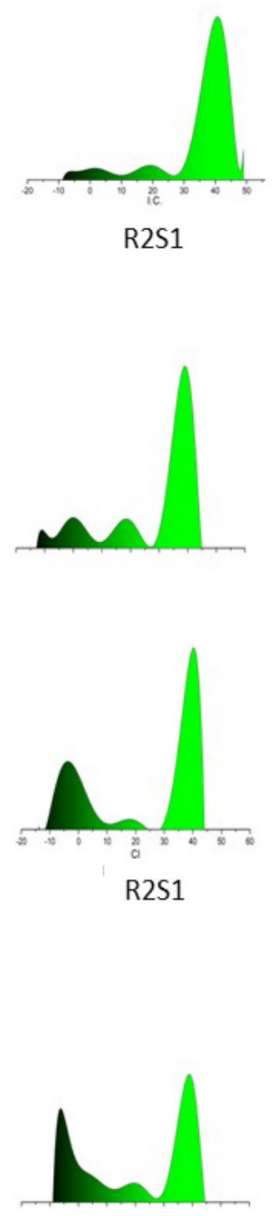

R2S1
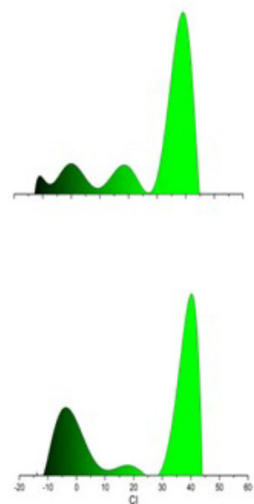

R2S1

B

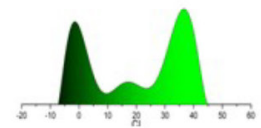

R2S1
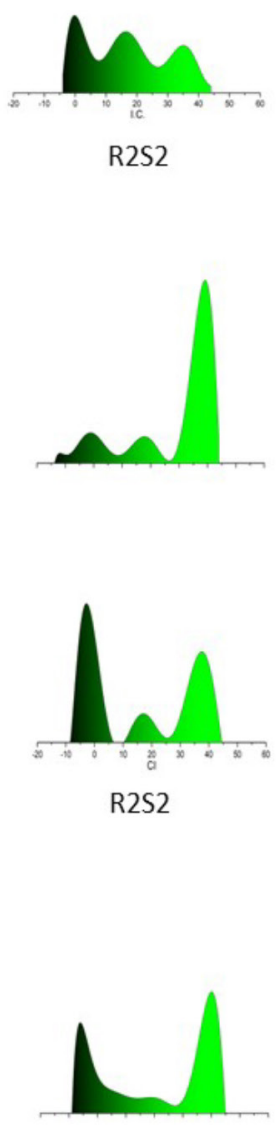

R2S2
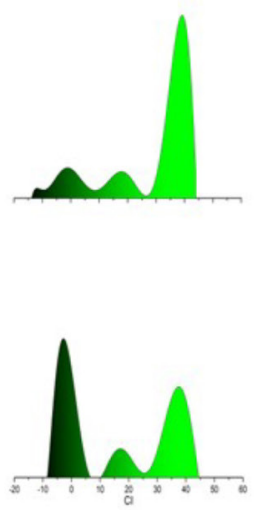

R2S2

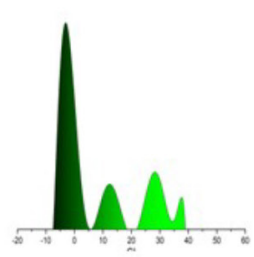

R2S2

FIGURE 3. Color index (CI) histogram values (non-linear curve fit) at day 0 and 14 for all possible combinations of two collection methods (R1: Manual Inverted Umbrella; R2: nets) and two storage methods (S1: ${ }^{\circ} \mathrm{C}$; S2: room temperature) for 'Arbequina' (A); 'Picual' (B) and 'Verdial' cultivar (C). 
by the interaction of ST and R, ST and S, R and S, and for the triple interaction of these factors. Both varieties showed a different profile in the changes of these parameters during storage time. From the initial storage time (day 0) all the varieties tested showed higher values for this parameter when they were harvested with nets (R2). However, from the next sampling date (day 4) they showed different profiles. Whereas in 'Arbequina' olives these differences decreased during the following two sampling dates and increased in the last one, in 'Picual' olives the differences had increased on the second and the third sampling dates and decreased on the last one. Finally, in 'Verdial' olives these differences had decreased by the second sampling date of storage, but, subsequently, only increased in the fruit stored at room temperature.

\section{DISCUSSION}

\subsection{Incidence of decay}

The fact that the effect of recollection was more evident than storage is not surprising, although the fruit harvested using both systems did not show differences in the incidence of physiological deterioration at the moment of harvesting (data not shown). Yousfi et al. (2012). compared the effect of 'Arbequina' olives picked using two different harvesting systems (hand and mechanical with an adapted wine grape harvester) during cold storage. Although they did not appreciate any differences in the appearance of the fruit immediately after harvesting, subsequently they found an exponential increase in decay incidence in mechanically-harvested fruit stored at $3{ }^{\circ} \mathrm{C}$. In contrast, hand-harvested fruit was not significantly decayed after two weeks of cold storage. In the present study, the differences between R1 and R2 can be explained because the use of R2 inevitably implies the involuntary treading on of the fallen fruit by the operators and the dragging over the ground of the fruit on the nets during its displacement to the next tree until reaching the filling of the boxes. This infers a serious risk of infection with soil pathogens, given the micro-wounds that this activity inevitably provokes. The effect of cold storage $\left(5^{\circ} \mathrm{C}\right)$, maintaining initial physiological integrity has been observed in different works, using different olive cultivars (Castellano et al., 1993; García et al., 1996; Rinaldi et al., 2010). In this study, the effect of $S 1$ proved to be more evident with the progression of the storage period, whereas the effect of R1 was already noticeable from the second sampling date (4 days). Cold storage requires the combined effect of a careful harvest to maintain a minimum amount of decay in the stored fruit.

\subsection{Weight loss}

As expected, the storage temperature determined the level of fruit transpiration and, consequently, the olives maintained under refrigeration showed lower weight loss than the ones kept in ambient conditions. In contrast, the harvesting method did not show any effect on this parameter. Yousfi et al. (2012) found the same effect of low temperature delaying the progress of weight loss during the storage of 'Arbequina' olives, and they also observed a significant effect due to the recollection method because the use of an adapted grape harvester turned out to be more damaging to fruit than when picked by hand. The results presented in this study should be placed between these two extremes. They are higher than the ones obtained by hand-harvest and lower than when compared with the adapted grape harvester.

\subsection{Skin color}

As for weight loss, the observed shift in skin color was only produced by storage temperature. Room temperature accelerated changes in the skin color, while refrigeration delayed it. This fact was previously observed in 'Picual' olives by Castellano et al. (1993) and by Yousfi et al., (2012) using 'Arbequina' fruit. In this paper, the appearance of the three model profiles when stored at room temperature typified this gradual color shift in the three studied varieties.

\subsection{Firmness}

The observed changes in firmness showed a similar process as discussed by Yousfi et al. (2012). As the storage time progressed, this parameter decreased in all the combinations of treatments, but fruit refrigeration delayed this softening. Furthermore, the damaging action of the harvest method used is related to this process. While in the study by Yousfi et al. (2012) the internal partial breaking of the cellulose wall of the olive mesocarp cells was a consequence of the mechanical harvesting method, in this study the responsible agent was related to the use of nets.

\subsection{Respiration rate and ethylene production}

Low temperature produces a decrease in the respiration rate. Maintaining the fruit at $5{ }^{\circ} \mathrm{C}$ produced a reduction in the metabolism of the fruit cells; while fruit kept at room temperature continued its normal activity, including respiration (Rinaldi et al., 2010). The concentration of substrates for respiration (sugar, fatty acid, etc.) is limited for detached fruit. The olives stored at room temperature consumed these soluble substrates continuously; while refrigerated fruit still disposed of a higher concentration of these metabolites when brought at $20{ }^{\circ} \mathrm{C}$ for respiration measurements. These processes explain the higher $\mathrm{CO}_{2}$ production levels in refrigerated fruit. Meanwhile, the higher respiration rate showed by 'Arbequina' olives harvested with nets could be attributed to its damaging 
action, which can accelerate this parameter. Segovia-Bravo et al. (2011) found a higher $\mathrm{CO}_{2}$ production in naturally bruised Manzanilla olives than in the healthy ones. Similarly, Morales-Sillero et al. (2015) observed that the fruit of two varieties (Manzanilla de Sevilla and Manzanilla Cacereña), harvested with a grape straddle harvester, showed a higher respiration rate than the hand-picked ones. They related this fact to the damaging action of this harvest method. Jimenez et al. (2017) demonstrated that the internal damage at morphological and histological levels differed between these varieties. In this study, 'Arbequina' olives seemed to be more sensitive to the action of the nets during harvest than 'Picual' and 'Verdial' olives.

The significantly higher amounts of ethylene synthesized by R2 harvested fruit indicated that this method was more damaging to the olive physiology than R1. This result coincides with that obtained by Morales-Sillero et al. (2017), who studied the ethylene production of Manzanilla and Cacereña olives stored at $2{ }^{\circ} \mathrm{C}$, which were harvested by hand or mechanically, using a grape straddle harvester. They found a significantly higher ethylene biosynthesis in the mechanically harvested fruit and identified this with the fact that this harvesting method was more detrimental to fruit integrity. Other causes for the increase in ethylene biosynthesis could be the natural progression of fruit ripening (Ardilla et al., 2012; Hyodo, 2018). When the R2S1 'Arbequina' olives were placed at $20{ }^{\circ} \mathrm{C}$ to measure their ethylene production it could be considered normal that they experimented a higher synthesis than the R1 ones because they were more damaged, but they showed significantly lower values for this parameter than R2S2 fruit, which was also damaged but with a higher level of ripening because it was maintained at a higher temperature during storage. R1 'Arbequina' olives showed the same behavior during the first three sampling dates because they were not damaged but the value increased because ripening had progressed. Finally, on the last sampling date, the olives stored at a higher temperature showed a significantly higher ethylene production, evidencing a higher level of ripening. The profile of 'Picual' olives only differed from the one shown by 'Arbequina' olives in the maxima values exhibited by R2 olives in the third sampling date, followed by a clear reduction in this parameter during the last moment of storage. This was probably due to a particular characteristic of this variety, in which ethylene biosynthesis would only coincide with ripening at the beginning of this process. R1S2 'Picual' olives did not show increasing values for this parameter at the end of the storage period when the ripening level of these olives was probably more evident. In contrast, the progression of ripening was better controlled by the cold storage in R1S1 olives, which showed the lowest ethylene production without changes throughout the storage period. The low values for ethylene production shown by
S1 'Verdial' olives could be related to better control of the ripening process due to cold storage. In contrast, fruit maintained at ambient temperature from the second sampling date showed increasing values for this parameter, which could be related to an accelerated ripening. Each variety showed a particular profile of ethylene production, due to its characteristics, such as sensitivity to the harvest system, response to cold storage, or the progression of ripening.

\section{CONCLUSIONS}

The better maintenance of the fruit's physiological conditions due to the harvesting method was demonstrated by the delay that it experienced during storage in its development of decay incidence and the significantly lower release of ethylene, regardless of the variety tested. Furthermore, cold storage induced a delay in weight loss, in changes in skin color, and the softening of the stored fruit. The treatment which used the combination of R1 and S1 systematically showed the best values for the fruit quality parameters tested. This combination of treatments offers a better guarantee than the traditional system (R2 and S2) to obtain a higher level of fruit physiological quality, either for the extraction of its oil, as for its table dressing.

\section{ACKNOWLEDGMENTS}

This work was funded by the Spanish Ministry of Science and Innovation (research project AGL201571585-R). We also thank the Del Cetino Olive Farm and their personnel for their collaboration and Carmen Martínez for her technical assistance.

\section{REFERENCES}

Aguilera Puerto D, Cáceres Moreno O, Martínez Gila D. 2019. Online system for the identification and classification of olive fruits for the olive oil production process. Food Measure 13, 716-727. https://doi. org/10.1007/s11694-018-9984-0

Ardilla T, Redondo-Cuadrado MJ, Gallardo M, SánchezCalle IM, Gómez-Jimenez MC. 2012. The interaction between ethylene and polyamines during ripening of olive fruit. Acta Hortic. 949, 147-154. https://doi. org/10.17660/ActaHortic.2012.949.20

Canet M, García JM. 1999. Repercusión de la frigoconservación de la aceituna de molino en el proceso de producción de aceite de oliva virgen. Grasas Aceites 50, 181-184. https://doi.org/10.3989/gya.1999.v50. i3.653

Castellano JM, García JM, Morilla A, Perdiguero S, Gutiérrez F. 1993. Quality of 'Picual' olive fruit under controlled atmospheres. J. Agric. Food Chem. 41, 537-539. https://doi.org/10.1021/jf00028a005 
Cátedra Caja Rural de Jaén. 2020. Informe anual de coyuntura del sector oleícola. Jaén: Caja Rural de Jaén.

Colombo S, Villanueva M. 2018. Inefficiency due to parcel fragmentation in olive orchards. Acta Hortic. 1199, 159-164. https://doi.org/10.17660/ActaHortic.2018.1199.26

Famiani F, Farinelli D, Urbani S, Al Hariri R, Paoletti A, Rosati A, Esposto S, Selvaggini R, Taticchi A, Servili M. 2020. Harvesting system and fruit storage affect basic quality parameters and phenolic and volatile compounds of oils from intensive and super-intensive olive orchards. Scientia Horticulturae 263, 109045. https://doi.org/10.1016/j.scienta.2019.109045

García JM, Yousfi K. 2006. The postharvest of mill olives. Grasas Aceites 57, 16-24. https://doi.org/10.3989/ gya.2006.v57.i1.18

García JM, Gutiérrez F, Barrera M, Albi M. 1996. Storage of Mill Olives on an Industrial Scale. J. Agric. Food Chem. 44, 590-593. https://doi.org/10.1021/jf950479s

Hyodo H. 2018. Stress/wound ethylene, in: Mattoo AK (ed.), The Plant Hormone Ethylene. CRC Press, Boca Raton, pp. 43-64. https://doi.org/10.1201/9781351075763

Jimenez MR, Casanova L, Suarez MP, Rallo P, Morales-Sillero A. 2017. Internal fruit damage in table olive cultivars under superhigh-density hedgerows. Postharvest Biology and Technology 132, 130-137. https://doi.org/10.1016/j.postharvbio.2017.06.003

Junta de Andalucía. Consejeria de Agricultura, Pesca y Desarrollo Rural, 2015. Análisis de las plantaciones de Oliver en Andalucía. Año 2015. Encuestra sobre Superficies y Rendi-mientos de Cultivos en España (ESYRCE), Sevilla: Junta de Andalucía. Servicio de Estudios y Estadísticas.

Morales-Silero A, García JM. 2015. Impact assessment of mechanical harvest on fruit physiology and consequences on oil physicochemical and sensory quality from 'Manzanilla de Sevilla' and 'Manzanilla Cacereña' super-high-density hedgerows. A preliminary study. J. Sci. Food Agric. 95, 2445-2453. https://doi. org/10.1002/jsfa.6971

Morales-Sillero A, Pérez A, Casanova L, García JM. 2017. Cold storage of 'Manzanilla de Sevilla' and
'Manzanilla Cacereña' mill olives from super-high density orchards. Food Chem. 237, 1216-1225. https://doi.org/10.1016/j.foodchem.2017.06.073

Navarro Soto J, Satorres Martinez S, Martínez Gila D, Gómez Ortega J, Gámez García J. 2018. Fast and Reliable Determination of Virgin Olive Oil Quality by Fruit Inspection Using Computer Vision. Sensors 18, 3826. https://doi.org/10.3390/s18113826

Plasquy E, Sola-Guiraldo R, Florido C, Blanco-Roldán G. 2019. Evaluation of a Manual Olive Fruit Recollector for Small Producers. Res. Agr. Eng. 65, 105111. https://doi.org/10.17221/18/2019-RAE

Puerto D, Gila D, García J, Ortega J. 2015. Sorting Olive Batches for the Milling Process Using Image Processing. Sensors 15, 15738-15754. https://doi. org/10.3390/s150715738

Rallo L, Díez MC, Morales-Sileros A, Miho H, Priego-Capote F, Rallo P. 2018. Quality of olives: A focus on agricultural preharvest factors. Scientia Horticulturae 233, 491-509. https://doi.org/10.1016/j. scienta.2017.12.034

Rinaldi R, Amodio M, Colelli G, Clodoveo M. 2010. Controlled atmosphere storage of 3 Italian cultivars of olives for oil production. Acta Hortic. 857, 97106. https://doi.org/10.17660/ActaHortic.2010.857.9

Segovia-Bravo K, García-García P, López-López A, Garrido-Fernández A. 2011. Effect of bruising on respiration, superficial colour and phenolic changes in fresh Manzanilla olives (Olea europea pomiformis): Development of treatments to mitigate browning. J. Agric. Food Chem. 59, 5456-5465. https://doi. org/10.1021/jf200219u

Serrano N, Romancho F, Arquero O. 2012. Estado del olivar en Andalucía. Necesidad y criterios de reconversión del olivar tradicional. Revista Fruticultura 24, 4-19.

Yousfi K, Weiland C, García JM. 2012. Effect of Harvesting System and Fruit Cold Storage on Virgen Olive Oil Chemical Composition and Quality of Superintensive Cultivated 'Arbequina' Olives. J. Agric. Food Chem. 60, 4743-4750. https://doi.org/10.1021/ jf300331q 